\title{
Genome-wide identification and expression analysis of rice NLR genes responsive to the infections of Xanthomonas oryzae pv. oryzae and Magnaporthe oryzae
}

\section{Li Ding}

Yangzhou University

\section{Xiameng Xu}

Shanghai Jiao Tong University

Weiwen Kong ( $\sim$ wwkong@yzu.edu.cn )

Yangzhou University https://orcid.org/0000-0002-5372-7110

Xue Xia

Yangzhou University

Shengwei Zhang

Yangzhou University

Aixin Liu

Shandong Agricultural University

Lifang Zou

Shanghai Jiao Tong University

Original article

Keywords: Rice, NLR genes, Transcriptional regulation, Xanthomonas oryzae pv. oryzae, Magnaporthe oryzae

Posted Date: December 18th, 2019

DOl: https://doi.org/10.21203/rs.2.19146/v1

License: (c) (1) This work is licensed under a Creative Commons Attribution 4.0 International License. Read Full License

Version of Record: A version of this preprint was published at Physiological and Molecular Plant Pathology on August 1st, 2020. See the published version at https://doi.org/10.1016/j.pmpp.2020.101488. 


\section{Abstract}

\section{Background}

Nucleotide-binding site, leucine-rich repeat (NLR) genes play a critical role in rice disease resistance. However, the transcriptional activities of rice NLR genes during pathogen invasions are still unclear.

\section{Results}

To uncover the veil, we identified a total of 430 regular rice NLR genes with both NBS and LRR domains, consisting of $192 \mathrm{CNL}$ and $238 \mathrm{XNL}$ (without a CC motif) members. We performed individual and integrative analyses based on 69 samples from rice microarray after the infections of Xanthomonas oryzae pv. oryzae (Xoo) and Magnaporthe oryzae (Mor). 397 NLR genes were found to be expressed at low/medium level, while 10 NLR genes were observed to show high levels of expression. 400 NLR genes were discovered to be differentially expressed in at least one sample. Further, 46 NLR genes were identified to be differentially expressed in rice response to the two pathogens and 38 of them could be validated by RNA-seq data. Six cis-regulatory elements (MYC, STRE, MYB, ABRE, G-box, and AS-1) were observed to occur frequently in the promoter regions of rice NLR genes. Ten NLR genes were selected for in lab analysis, and qRT-PCR results of seven NLR genes verified the validity of the microarray and RNASeq data.

\section{Conclusions}

Our results would shed new light on revealing the roles of NLR genes in rice resistance to Xoo and Mor.

\section{Background}

During their life cycles, plants are exposed to a plethora of complex pathogen stresses. These pathogens could be harmful to their survival and growth. A variety of pathogens pose a serious threat to global crops, and the accompanying problems such as the decline in yield and quality have plagued breeders and plant pathologists for many years (Moffat 2001).

Unlike most animals that are able to move and escape from harmful conditions, plants can only rely on themselves to suppress the pathogen attacks. Fortunately, during the process of evolution, plants have developed an innate immune system consisting of pathogen-associated molecular pattern (PAMP)triggered immunity (PTI) and effector-triggered immunity (ETI) which enable them to counter the pathogens at the site of infection effectively(Chen and Ronald 2011; Dodds and Rathjen 2010; Jones and Dangl 2006). The first layer of the immune system, PTI, is mediated by some pattern recognition receptors (PRRs) that could recognize PAMPs while resistance $(R)$ proteins play a key role behind defense responses in ETI (Dodds and Rathjen 2010; Zipfel 2008). Although PTI and ETI trigger similar defense responses, ETI is much faster and stronger (Jones and Dangl 2006). 
Taking into account the importance of rice as a monocot model plant and valuable crop species, it is of great value to explore and elucidate the rice defense responses to different pathogens. It has been demonstrated that the processes of recognizing pathogen attacks and then initiating the defense responses in rice are mainly mediated by some specific determinants, including disease-resistance (R) genes (Gu et al. 2005; Yang et al. 2013). Among all the identified R genes, the largest class is nucleotidebinding, leucine-rich repeat (NLR) genes, which represent more than $80 \%$ of the identified $\mathrm{R}$ genes (McHale et al. 2006; Zhou et al. 2004). The NLR genes encode a variety of intracellular multi-domain proteins that directly or indirectly recognize pathogen-derived effectors (Wu et al. 2015). The NBL-LRR proteins usually consist of two conserved domains, i.e., nucleotide-binding site (NBS) domain and leucine-rich repeat (LRR) domain (McHale et al. 2006). The NBS domain is mainly responsible for signaling and has several highly conserved motifs. By contrast, the LRR domain is often related to protein-protein interactions and ligand binding with pathogen-derived molecules (DeYoung and Innes 2006; McHale et al. 2006). According to the toll interleukin 1 receptor domain (TIR) or coiled-coil (CC) domain contained at their amino terminal, NBS-LRR proteins can be further classified into two subclasses: TIR-NBS-LRR (TNL) and CC-NBS-LRR (CNL) (McHale et al. 2006; Monosi et al. 2004). However, most monocots like rice do not have TIR domains (Tarr and Alexander 2009). Previous studies have identified approximately 440 regular NLR genes in rice, which are located unevenly on the chromosome (Yang et al. 2006; Zhou et al. 2004). Although these NLR genes are considered to act as decisive players in rice disease resistance, their transcriptional activities are still to be elucidated during pathogen infections.

Xanthomonas oryzae pv. oryzae (Xoo) and Magnaporthe oryzae (Mor), which are the causal agents of rice bacterial blight disease and rice blast disease, respectively, are more widely used to explore the molecular interactions between rice and its pathogens. To date, a great number of rice bacterial blight resistance genes and rice blast resistance genes have been reported (http://ricedata.cn). By 2015, 38 rice bacterial blight resistance genes and 84 rice blast disease resistance genes have been identified (http://www.ricedata.cn/gene/gene_pi.htm).

In the last two decades, microarray-based studies have revolutionized the identification of genome-wide transcriptomic changes and opened a new vista for evaluating rice-pathogen interactions (Li et al. 2006; Seo et al. 2008). Although the data and results produced by these microarray-based studies are particularly significant, there is still a lot of valuable information remaining to excavate and analyze. On the other hand, previous microarray-based studies, however, focused on only a limited of conditions, such as restricted growth conditions, tissues, treatments, and stress levels. So a key question is: how can we best integrate multiple existing microarray studies under Xoo- and Mor-infected conditions to evaluate the transcriptomic profiling of NLR genes and identify the NLR genes highly responsive to pathogen infections?

Here, using a broad range of rice microarray data infected by Xoo and Mor, we performed an individual and integrative analysis to identify the robust and special rice NLR genes under Xoo- or Mor-infected conditions. We identified a set of potentially up-regulated rice NLR genes, which displayed both a high 
frequency of occurrence and a differential expression level when rice plants were subject to pathogen attack. The results would give a novel insight into the NLR genes which might be critical to rice defense responses.

\section{Results}

Identification of rice regular NLR genes at the genome level

More than 10 years ago, 530 NBS genes were identified at the rice genome, of which 440 are regular NLR genes (Zhou et al. 2004; Yang et al. 2006). From then on, the rice genome becomes more and more perfect. Thus, we re-excavated the rice NLR genes using updated rice genomic data. We obtained a total of 430 regular NLR genes, which consists of both NBS and LRR domains (Table S1). The 430 genomic loci were then converted into their corresponding probes. Since the probes did not correspond to all the genomic loci, 23 NLR genes were not discovered to have the corresponding probes, and 501 probes were found to match the remaining 407 NLR genes (Table S1).

Based on the presence and absence of a TIR motif in the N-terminal regions, NLR genes in Arabidopsis thaliana could be classified into TIR-NBS-LRR (TNL) and CC-NBS-LRR (CNL) (Meyers et al. 2003). However, our result showed that the 430 regular rice NLR genes contained no TIR domain (Table S1). Generally, non-TIR NLR gene from dicots typically has a Coiled-Coil (CC) motif in the N-terminal region (Tarr and Alexander 2009), so we next performed a CC motif search for these 430 rice NLR genes using the COILS Sever (https://embnet.vital-it.ch/software/COILS_form.html). Previous studies showed that 160 of the 440 regular rice NLR genes identified were CNL genes (Zhou et al. 2004). In our analysis, we found 192 CNL and 238 XNL (without a CC motif) genes (Table S1).

The NLR genes' expression profiling under pathogen-infected conditions by integrative microarray analysis

In order to evaluate the expression profiles of rice NLR genes induced by Xoo and Mor, we analyzed a great number of microarray samples (Table S2). To avoid the variance of different platforms, the microarray data for analysis were selected from the same rice platform GPL2025. All the 69 sets of samples consisted of various rice genotypes and growth stages, diverse pathogen strains, different inoculated methods, and sampling times (Table 1; Table S2). Based on the number of occurrence in different expression ranges (out of 69 sets of samples), 407 rice NLR genes (matched by 501 probes) were considered for evaluating the gene expression levels. The expression levels of 407 NLR genes were divided into three groups: low ( $<1.0$ fold-change), medium ( $\geq 1.0$ and $<1.5$ fold-change), and high ( $\geq 1.5$ fold-change). Most of the NLR genes (397/407) were found to present low or medium levels of expression, and only 10 NLR genes showed high levels of expression (Fig. 1 and Table S3). No NLR genes were found to be expressed at very low level ( $<0.5$ fold-change), indicating that no NLR genes were highly repressed by Xoo or Mor in all the 69 samples. 


\begin{tabular}{|lll|}
\hline \multicolumn{3}{|l|}{ Table 1. Summary of the microarray samples used in this study. } \\
\hline & Sample infected by Xoo & Sample infected by Mor \\
\hline Number of sample & 51 & 18 \\
\hline Rice genotype & 10 & 5 \\
\hline Rice stage & from 14 to 75 days old & from 14 to 28 days old \\
\hline Pathogen strain & 10 & 8 \\
\hline Inoculated tissue & leaf & leaf, root \\
\hline Inoculated method & infiltration/leaf-clipping & spore suspension \\
\hline Sampling time & from 2 to 96 hpi & from 12 to $144 \mathrm{hpi}$ \\
\hline
\end{tabular}

The differentially expressed NLR genes (de_NLRs) induced by Xoo- and Mor-infections in rice

To further reveal the differential expression of the above 407 rice NLR genes in the 69 microarray samples, the threshold of p.value $<0.05$ was set to screen the de_NLRs. The results showed that the number of the de_NLRs in all the 69 samples varied from 10 to 172 (out of 407 NLR genes) (Table S4); and in 40 samples, the number of the de_NLRs differed from 51 to 100 depending on diverse samples (Fig. 2). This unbalance may be caused by different conditions in diverse experiments. In all the 69 samples, the frequency of occurrence of the de_NLRs was observed to range from 0 to 39 (Table S5). Of all the 407 rice NLR genes identified, 400 NLR genes were observed to be differentially expressed in at least one sample, two NLR genes were detected to be differentially expressed in 39 samples and no NLR genes were found to be differentially expressed in all the 69 samples (Table S5).

In addition, we tested the statistical significance of the de_NLRs present in the whole rice genome. Based on the over-representation method (Khatri et al. 2012), we performed a gene enrichment analysis on rice genes and compared the significant relationship between all the de_NLRs and all the rice differentially expressed genes (DEGs). We found that only 8 groups of samples showed high enrichment of the de_NLRs compared to the total rice DEGs, and the de_NLRs in the 39 samples showed a lower incidence compared to the DEGs in the whole rice genome (Figure S1; Table S6). This indicates that although the rice NLR genes were thought to be highly required for pathogen perception and defense responses, they exhibited different expression profiles under different experimental conditions.

The robust pathogen-responsive rice NLR genes identified by integrative microarray analysis

To further determine how many rice NLR genes could simultaneously show high expression level and significant differential expression, we examined the relationship between the occurrence of these 407 NLR genes which presented greater or equal to 1.5 fold-change and the percentage of these genes which showed a p-value of less than 0.01 . The combination of two empirically rigorous filters could help us obtain a more reliable set of pathogen-responsive NLR genes in rice. 
As shown in Fig. 3, among the 1.5 fold-change line, the most dramatic decrease occurred in less than 17 out of 69 samples. As the frequency of occurrence increased, the percentage of significance at the 0.01 level also rose gradually and reached about $95 \%$ in 17 out of 69 samples. Based on this result, we speculated that a cutoff of more than 16 would capture a convincing set of pathogen-responsive NLR genes. Hence, two filters were then used to query NLR genes: a) genes showing an increased expression with a greater than 1.5 fold-change in at least 17 samples; b) genes that had a p-value of 0.01 or less in the Fisher's test. Using this approach, a set of 46 rice NLR genes were identified in the rice response to the two pathogens (Table 2). These putative rice NLR genes displayed a high frequency of differential expression under different pathogen-infected conditions and were further defined as robust pathogenresponsive rice NLR genes. 
Table 2

List of 46 pathogen-responsive rice NLR genes identified by the integratedanalysis.

\begin{tabular}{|c|c|}
\hline Chromosome & Gene ID \\
\hline \multirow[t]{3}{*}{ Chr1 } & LOC_Os01g57870 \\
\hline & LOC_Os01g70080 \\
\hline & LOC_Os01g72680 \\
\hline \multirow[t]{3}{*}{ Chr2 } & LOC_Os02g16060 \\
\hline & LOC_Os02g18000 \\
\hline & LOC_Os02g18080 \\
\hline \multirow[t]{3}{*}{ Chr3 } & LOC_Os03g20840 \\
\hline & LOC_Os03g50150 \\
\hline & LOC_Os03g63150 \\
\hline \multirow[t]{6}{*}{ Chr4 } & LOC_Os04g02030 \\
\hline & LOC_Os04g02110 \\
\hline & LOC_Os04g25900 \\
\hline & LOC_Os04g30930 \\
\hline & LOC_Os04g43340 \\
\hline & LOC_Os04g43440 \\
\hline \multirow[t]{2}{*}{ Chr5 } & LOC_Os05g34220 \\
\hline & LOC_Os05g41310 \\
\hline Chr6 & LOC_Os06g49390 \\
\hline Chr7 & LOC_Os07g17250 \\
\hline \multirow[t]{4}{*}{ Chr8 } & LOC_Os08g14850 \\
\hline & LOC_Os08g16120 \\
\hline & LOC_Os08g29809 \\
\hline & LOC_Os08g42700 \\
\hline \multirow[t]{2}{*}{ Chr9 } & LOC_Os09g09490 \\
\hline & LOC_Os09g14450 \\
\hline
\end{tabular}




\begin{tabular}{|c|c|}
\hline \multirow[t]{3}{*}{ Chromosome } & Gene ID \\
\hline & LOC_Os09g34150 \\
\hline & LOC_Os09g34160 \\
\hline \multirow[t]{2}{*}{ Chr10 } & LOC_Os10g04120 \\
\hline & LOC_Os10g36270 \\
\hline \multirow[t]{12}{*}{ Chr11 } & LOC_Os11g11770 \\
\hline & LOC_Os11g11960 \\
\hline & LOC_Os11g12000 \\
\hline & LOC_Os11g12050 \\
\hline & LOC_Os11g12330 \\
\hline & LOC_Os11g12340 \\
\hline & LOC_Os11g16470 \\
\hline & LOC_Os11g37050 \\
\hline & LOC_Os11g38440 \\
\hline & LOC_Os11g38520 \\
\hline & LOC_Os11g42660 \\
\hline & LOC_Os11g45930 \\
\hline \multirow[t]{5}{*}{ Chr12 } & LOC_Os12g10180 \\
\hline & LOC_Os12g10710 \\
\hline & LOC_Os12g13550 \\
\hline & LOC_Os12g28100 \\
\hline & LOC_Os12g37770 \\
\hline
\end{tabular}

Further validation of the expression of the 46 pathogen-responsive rice NLR genes by RNA-seq data To further validate the reliability of 46 candidate pathogen-responsive NLR genes, we compared them against lists of rice genes that showed differential expression in six rice RNA-seq datasets. These RNAseq data included interactions between rice and Magnaporthe oryzae as well as between rice and Rhizoctonia solani. We found that the expression levels of the 46 NLR genes obtained from the RNA-seq data were very similar to those from the microarray data. Among all the 46 NLR genes, 38 were detected to be differentially expressed in at least one set of the RNA-seq data, and 15 genes were detected to be differentially expressed in at least three sets of the RNA-seq data (Table 3). Therefore, the 38 NLR genes 
could be detected by both the microarray data and the RNA-seq data, indicating they are active in the response to the rice pathogens (Fig. 4). 
Table 3

List of the golden list rice NLR genes $(F C \geq 1.5)$ frequently responsive to Xoo and Mor.

\begin{tabular}{|lll|}
\hline Gene ID & $\begin{array}{l}\text { Frequency in } \\
\text { microarray data }(\mathbf{n}=\mathbf{6 9})\end{array}$ & $\begin{array}{l}\text { Frequency in } \\
\text { RNA-seq data }(\mathbf{n}=\mathbf{6})\end{array}$ \\
\hline LOC_Os01g70080 & 34 & 5 \\
\hline LOC_Os11g12340 & 25 & 5 \\
\hline LOC_Os12g13550 & 21 & 5 \\
\hline LOC_Os02g18080 & 21 & 4 \\
\hline LOC_Os11g11960 & 18 & 4 \\
\hline LOC_Os11g12000 & 21 & 4 \\
\hline LOC_Os12g10710 & 21 & 4 \\
\hline LOC_Os03g20840 & 32 & 3 \\
\hline LOC_Os07g17250 & 21 & 3 \\
\hline LOC_Os08g42700 & 19 & 3 \\
\hline LOC_Os09g34150 & 33 & 3 \\
\hline LOC_Os09g34160 & 26 & 2 \\
\hline LOC_Os11g37050 & 24 & 3 \\
\hline LOC_Os11g45930 & 18 & 2 \\
\hline LOC_Os12g37770 & 30 & 2 \\
\hline LOC_Os03g63150 & 18 & 2 \\
\hline LOC_Os04g02030 & 18 & 3 \\
\hline LOC_Os04g43440 & 39 & 2 \\
\hline LOC_Os05g34220 & 24 & 2 \\
\hline LOC_Os11g12050 & 18 & 2 \\
\hline LOC_Os11g12330 & 18 & 2 \\
\hline LOC_Os11g38520 & 24 & 3 \\
\hline LOC_Os12g10180 & 30 & 2 \\
\hline LOC_Os12g28100 & 20 & 2 \\
\hline LOC_Os01g57870 & 18 & 2 \\
\hline
\end{tabular}




\begin{tabular}{|c|c|c|}
\hline Gene ID & $\begin{array}{l}\text { Frequency in } \\
\text { microarray data }(n=69)\end{array}$ & $\begin{array}{l}\text { Frequency in } \\
\text { RNA-seq data }(n=6)\end{array}$ \\
\hline LOC_Os01g72680 & 19 & 1 \\
\hline LOC_Os02g18000 & 18 & 1 \\
\hline LOC_Os04g02110 & 20 & 1 \\
\hline LOC_Os04g25900 & 20 & 1 \\
\hline LOC_Os04g30930 & 19 & 1 \\
\hline LOC_Os04g43340 & 17 & 1 \\
\hline LOC_Os06g49390 & 19 & 1 \\
\hline LOC_Os08g16120 & 17 & 1 \\
\hline LOC_Os09g09490 & 20 & 1 \\
\hline LOC_Os09g14450 & 18 & 1 \\
\hline LOC_Os10g04120 & 17 & 1 \\
\hline LOC_Os10g36270 & 17 & 1 \\
\hline LOC_Os11g11770 & 22 & 1 \\
\hline
\end{tabular}

Expression patterns of the rice NLR genes detected in both microarray and RNA-seq data

To obtain the detailed expression patterns of the above 38 NLR genes examined in microarray and RNAseq data, the OmicShare tool (https://www.omicshare.com/) was used to conduct a heat map analysis based on the expression values (log2 fold-change between infected and control samples) obtained from the 69 individual experiments. Strikingly, the 38 rice NLR genes showed very similar expression patterns (Figure S2). They presented highly up-regulated expressions under most of the experimental conditions and down-regulated expressions only in a few experiments (Figure S2), showing that they were active in rice response to the two pathogens and suggesting that they play important roles in rice against the pathogens.

The putative cis-regulatory elements in the promoters of 38 rice NLR genes

Our previous study has shown that there are four pathogen-inducible cis-regulatory elements (PICEs) (Gbox, AS-1, GCC-box, and H-box) in the promoter regions of some rice genes, which are critical for the genes' response to pathogen attacks (Kong et al. 2018). Understanding the upstream regulators of rice NLR genes will definitely extend our knowledge of the expression of the NLR genes in rice defense response. Here, we examined the 2000 bp upstream promoter regions of the above 38 NLR genes which 
were detected in both microarray and RNA-seq data to determine if the PICEs exist. Besides two core promoter elements (TATA box and CAAT box), we identified six cis-regulatory elements that occur frequently in the promoter regions, which were MYC, STRE, MYB, ABRE, G-box, and AS-1 (Fig. 5).

We found that the top four elements were MYC, STRE, MYB, and ABRE, and their occurrences exceeded 100 times (Fig. 5). The presence of MYB and MYC elements in the promoters suggests they are potential binding sites for MYB and MYC transcription factors, respectively. These two transcription factors have been revealed to play significant roles in plant defense against various stresses (Fang et al. 2018; Feng et al. 2013; Wu et al. 2019). When the MYB and MYC transcription factors bind to their corresponding cisregulatory elements, they regulate a range of genes associated with biotic or abiotic stresses (Ambawat et al. 2013; Dubos et al. 2010; Ogata et al. 1994). In addition, the STRE and ABRE elements are stressresponsive elements that were extensively studied; the former is a typical stress-responsive element and the latter is an abscisic acid response element (Fujita et al. 2005; Moskvina et al. 1999; Narusaka et al. 2003).

It is worth noting that G-box and AS-1 are also occurring with high frequency, and these two cis-regulatory elements have been shown to be implicated in the induced expression of some genes after pathogen attacks (Loake et al. 1992; Ulmasov et al. 1994; Xiang et al. 1996). Several studies have reported that AS1 cis-regulatory element could be bound by the TGA family of the basic-leucine zipper (bZIP) transcription factors and then activate the initial plant defense against pathogen attack (Despres et al. 2000; Sarkar et al. 2018). G-box was found to be bound by G/HBF-1, which is also a bZIP protein, for inducing the expressions of some defense genes (Droge-Laser et al. 1997). In addition, G-box also has been demonstrated to be bound by the MYC proteins and basic/helix-loop-helix (bHLH) proteins(Boter et al. 2004; Toledo-Ortiz et al. 2003). We speculate that the interactions of PICEs present in NLR genes' promoter regions with their corresponding transcription factors are required for the transcriptional activation of some rice NLR genes.

Validation of selected NLR genes by qRT-PCR

To further evaluate the 38 pathogen-responsive NLR genes identified in this work, the top five upregulated genes were selected for qRT-PCR analysis. In addition, another five NLR genes, which displayed a high frequency of down-regulation during infection with pathogens, were also used for validation. As shown in Fig. 6, three of the five identified up-regulated NLR genes displayed highly significant increases (p-value < 0.05) at 24 hpi in PX099A-infected samples. But the rest two NLR genes (LOC_Os09g34150 and LOC_Os12g10180) were down-regulated by PX099A , which were inconsistent with the microarray and RNA-Seq data (Fig. 6). As for the down-regulated gene set, the expression levels of four members (LOC_Os12g32660, LOC_Os11g35210, LOC_Os05g30220 and LOC_Os06g41660) were significantly

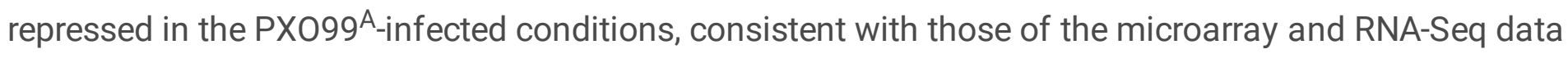
(Fig. 6). There was also one gene, LOC_Os01g16370, which showed an opposite trend of expression change in response to $\mathrm{PXO99}^{\mathrm{A}}$ inoculation (Fig. 6). 
In all, the results above showed a similar overall trend with the microarray analysis and they also demonstrated the reliability of the pathogen-responsive rice NLR genes identified in this work. The discrepancy between the qRT-PCR results and the microarray results for 3 NLR genes may be due to the different infected rice samples used.

Examination of the expression of 30 NLR genes without detection by microarray data

We found that 23 rice NLR genes had no corresponding probes and other 7 rice NLR genes could not be detected differential expression at the transcriptional level in the microarray data. We hence wondered whether these 30 NLR genes could be detected to be differentially expressed by RNA-seq data. Analyses of six published RNA-seq data showed that, of the 7 NLR genes examined, only two (LOC_Os12g09240 and LOC_Os11g42770) were detected at least one differential expression in the RNA-seq data (Table 4). LOC_Os12g09240 was found to show high levels of expression (>1.8 fold) and LOC_Os11g42770 was observed to show a low level of expression ( $<1.0$ fold) (Table 4). Out of the 23 NLR genes that had no corresponding probes, ten (43\%) were detected to show at least one differential expression (Table 4). Among these ten NLR genes, five could be detected to be differentially expressed in at least two sets of the RNA-seq data (Table 4). These data demonstrate that twelve of the 30 NLR genes had the potential to express in rice defense response. 
Table 4

Detection of differential expression of 30 rice NLRs in 6 groups of RNA-seq data.

\begin{tabular}{|c|c|c|c|c|}
\hline Gene_ID & Type & $\begin{array}{l}\text { Number of } \\
\text { differential } \\
\text { expression }\end{array}$ & $\begin{array}{l}\text { The maximum } \\
\text { value of fold } \\
\text { change }\end{array}$ & $\begin{array}{l}\text { The minimum } \\
\text { value of fold } \\
\text { change }\end{array}$ \\
\hline LOC_Os12g09240 & $\begin{array}{l}\text { Could not be } \\
\text { detected in } \\
\text { microarray }\end{array}$ & 2 & 3.8 & 2.8 \\
\hline LOC_Os11g42770 & $\begin{array}{l}\text { Could not be } \\
\text { detected in } \\
\text { microarray }\end{array}$ & 1 & 0.5 & 0.5 \\
\hline LOC_Os11g42580 & $\begin{array}{l}\text { Could not be } \\
\text { detected in } \\
\text { microarray }\end{array}$ & 0 & - & - \\
\hline LOC_Os12g10340 & $\begin{array}{l}\text { Could not be } \\
\text { detected in } \\
\text { microarray }\end{array}$ & 0 & - & - \\
\hline LOC_Os12g10360 & $\begin{array}{l}\text { Could not be } \\
\text { detected in } \\
\text { microarray }\end{array}$ & 0 & - & - \\
\hline LOC_Os12g10390 & $\begin{array}{l}\text { Could not be } \\
\text { detected in } \\
\text { microarray }\end{array}$ & 0 & - & - \\
\hline LOC_Os12g29710 & $\begin{array}{l}\text { Could not be } \\
\text { detected in } \\
\text { microarray }\end{array}$ & 0 & - & - \\
\hline LOC_Os06g48520 & $\begin{array}{l}\text { No } \\
\text { corresponding } \\
\text { probe }\end{array}$ & 4 & 5.3 & 1.3 \\
\hline LOC_Os11g12320 & $\begin{array}{l}\text { No } \\
\text { corresponding } \\
\text { probe }\end{array}$ & 3 & 2.9 & 1.5 \\
\hline LOC_Os08g05440 & $\begin{array}{l}\text { No } \\
\text { corresponding } \\
\text { probe }\end{array}$ & 2 & 1.8 & 0.4 \\
\hline LOC_Os11g39330 & $\begin{array}{l}\text { No } \\
\text { corresponding } \\
\text { probe }\end{array}$ & 2 & 0.5 & 0.2 \\
\hline LOC_Os12g17480 & $\begin{array}{l}\text { No } \\
\text { corresponding } \\
\text { probe }\end{array}$ & 2 & 0.9 & 0.5 \\
\hline
\end{tabular}




\begin{tabular}{|c|c|c|c|c|}
\hline Gene_ID & Type & $\begin{array}{l}\text { Number of } \\
\text { differential } \\
\text { expression }\end{array}$ & $\begin{array}{l}\text { The maximum } \\
\text { value of fold } \\
\text { change }\end{array}$ & $\begin{array}{l}\text { The minimum } \\
\text { value of fold } \\
\text { change }\end{array}$ \\
\hline LOC_Os04g53496 & $\begin{array}{l}\text { No } \\
\text { corresponding } \\
\text { probe }\end{array}$ & 1 & 0.9 & 0.9 \\
\hline LOC_Os06g20050 & $\begin{array}{l}\text { No } \\
\text { corresponding } \\
\text { probe }\end{array}$ & 1 & 27.3 & 27.3 \\
\hline LOC_Os08g32880 & $\begin{array}{l}\text { No } \\
\text { corresponding } \\
\text { probe }\end{array}$ & 1 & NA & NA \\
\hline LOC_Os10g07534 & $\begin{array}{l}\text { No } \\
\text { corresponding } \\
\text { probe }\end{array}$ & 1 & NA & NA \\
\hline LOC_Os11g45840 & $\begin{array}{l}\text { No } \\
\text { corresponding } \\
\text { probe }\end{array}$ & 1 & NA & NA \\
\hline LOC_Os02g16330 & $\begin{array}{l}\text { No } \\
\text { corresponding } \\
\text { probe }\end{array}$ & 0 & - & - \\
\hline LOC_Os04g02460 & $\begin{array}{l}\text { No } \\
\text { corresponding } \\
\text { probe }\end{array}$ & 0 & - & - \\
\hline LOC_Os04g30530 & $\begin{array}{l}\text { No } \\
\text { corresponding } \\
\text { probe }\end{array}$ & 0 & - & - \\
\hline LOC_Os06g41640 & $\begin{array}{l}\text { No } \\
\text { corresponding } \\
\text { probe }\end{array}$ & 0 & - & - \\
\hline LOC_Os08g07380 & $\begin{array}{l}\text { No } \\
\text { corresponding } \\
\text { probe }\end{array}$ & 0 & - & - \\
\hline LOC_Os09g11020 & $\begin{array}{l}\text { No } \\
\text { corresponding } \\
\text { probe }\end{array}$ & 0 & - & - \\
\hline LOC_Os11g30210 & $\begin{array}{l}\text { No } \\
\text { corresponding } \\
\text { probe }\end{array}$ & 0 & - & - \\
\hline LOC_Os11g45924 & $\begin{array}{l}\text { No } \\
\text { corresponding } \\
\text { probe }\end{array}$ & 0 & - & - \\
\hline
\end{tabular}




\begin{tabular}{|c|c|c|c|c|}
\hline Gene_ID & Type & $\begin{array}{l}\text { Number of } \\
\text { differential } \\
\text { expression }\end{array}$ & $\begin{array}{l}\text { The maximum } \\
\text { value of fold } \\
\text { change }\end{array}$ & $\begin{array}{l}\text { The minimum } \\
\text { value of fold } \\
\text { change }\end{array}$ \\
\hline LOC_Os12g10490 & $\begin{array}{l}\text { No } \\
\text { corresponding } \\
\text { probe }\end{array}$ & 0 & - & - \\
\hline LOC_Os12g17410 & $\begin{array}{l}\text { No } \\
\text { corresponding } \\
\text { probe }\end{array}$ & 0 & - & - \\
\hline LOC_Os12g17420 & $\begin{array}{l}\text { No } \\
\text { corresponding } \\
\text { probe }\end{array}$ & 0 & - & - \\
\hline LOC_Os12g30720 & $\begin{array}{l}\text { No } \\
\text { corresponding } \\
\text { probe }\end{array}$ & 0 & - & - \\
\hline LOC_Os12g30760 & $\begin{array}{l}\text { No } \\
\text { corresponding } \\
\text { probe }\end{array}$ & 0 & - & - \\
\hline
\end{tabular}

Additionally, we explored if there were factors repressing the expression of the remaining 18 NLR genes that could not be detected to be differentially expressed by either microarray or RNA-sEq. We initially described these 18 genes as the group A that contained NLR genes without differential expression, and then randomly selected 18 genes from the above differentially expressed NLR genes as the group B. By performing a motif search on both groups, we compared the highly frequent cis-regulatory elements in the upstream regions of the two groups of the genes, but did not observe any differences. In addition, we also examined the possible transposons within or adjacent to the NLR genes of the two groups, yet could not find any significant difference between group A and group B.

\section{Discussion}

In this work, we identified 430 regular NLR genes in rice (Oryza sativa L. ssp. japonica) based on the MSU Rice Genome Annotation Release 7. Our data demonstrated that all the NLR genes identified are non-TIR type, and the proportions of CNL and XNL subclasses are $45 \%$ and $55 \%$, respectively. Previous study identified 440 rice NLR genes (Zhou et al. 2004). We tried to conduct a comparative analysis of our work with this study, but we did not find any detailed information about their identification of 440 NLR genes by checking the webpage according to their report. Rice genome annotations have been continuously perfected in the past decade, and the updated rice genome annotations are more accurate than the past, thereby probably leading to an inconsistency between our result and the literature (Zhou et al. 2004). 
To identify robust and reliable rice NLR genes that respond to Xoo and Mor, we combined 69 microarray expression data of rice plants under Xoo- or Mor-infected conditions to perform an integrative analysis. Instead of using one screening criterion, a more rigorous statistical method was applied to obtain the statistically significant DEGs. In particular, this method could greatly improve the sensitivity and reliability of identifying the important rice NLR genes that may be missed by studies that focus on specific tissue or developmental stage.

We attempted to distinguish the 69 samples between compatible interactions and incompatible interactions, but we did not obtain enough information on the rice varieties or pathogen strains from some series of data, e.g., GSE36093, GSE61832, GSE61833, GSE33204 and GSE36272. We found that the number of differentially expressed NLR genes (de_NLRs) varied extremely with the range from 10 to 172 in the 69 samples (Table S4). Nevertheless, this reflects that the transcriptional activities of the rice NLR genes were regulated by diverse factors. However, the proportion of the de_NLRs to all the DEGs in most microarray and RNA-seq samples seemed relatively constant (Table S7), and only 10 samples (14\%) showed a significantly high enrichment of de_NLRs (Table S6). Thus, our results give new light on the expression patterns of rice NLR genes under various pathogen infection conditions.

In this work, we showed a set of 38 NLR genes displayed both a high frequency of occurrence and a differential expression pattern in rice response to Xoo- and Mor-infections. The set of NLR genes were robustly up-regulated by Xoo- and Mor-infections in rice plants, the results were supported by both some microarray data and RNA-seq data. In addition, all of the 38 NLR genes were supported by the results of differential expression analysis in previous studies (Table S8). Comparing these 38 NLR genes with previous studies, we found that 36 NLR genes displayed a differential expression under Mor-infected conditions (Bagnaresi et al. 2012; Chen et al. 2018; Jain et al. 2017; Lin et al. 2018; Onaga et al. 2017; Urso et al. 2015; Zhang et al. 2016). We also found that six NLR genes (LOC_Os10g36270, LOC_Os11g12340, LOC_Os11g37050, LOC_Os11g45930, LOC_Os12g10710 and LOC_Os11g11770) were activated in rice response to Xoo (Hur et al. 2016; Zhang et al. 2015). Interestingly, there are six NLR genes (LOC_Os02g18080, LOC_Os08g42700, LOC_Os12g10180, LOC_Os12g13550, LOC_Os10g04120 and LOC_Os11g11770) were also found to show differential expressions in response to Rhizoctonia solani infection (Zhang et al. 2017).

To verify our analysis, 10 identified NLR genes were selected for qRT-PCR detection. Seven out of the ten NLR genes were detected to be expectedly up-regulated by Xoo. However, the expressions of LOC_Os09g34150 and LOC_Os12g10180 were opposite to those of our microarray analysis. In spite of this, both of the genes have been reported to exhibit significant up-regulation under the infections of blast fungi (Bagnaresi et al. 2012; Zhang et al. 2016).

Our analysis also revealed some PICEs within the promoters of the 38 rice NLR genes, suggesting that the expression of these NLR genes could be potentially regulated by some transcription factors, e.g., MYB/MYC, SEB-1, Msn2/Msn4, and AREB1/AREB2/ABF3, under different biotic and abiotic stresses. These specific transcription factors are potentially of vital importance on regulating the spatio-temporal 
expression of rice NLR genes during pathogen attacks (Franco-Zorrilla et al. 2014; Kong et al. 2018; Singh et al. 2002). Therefore, our result provides key clues for further uncovering the mode of regulation of rice NLR genes' expressions.

We found that 30 NLR genes were difficult to assess their differential expression level through 69 microarray samples. This may be due to the lack of corresponding probes or due to the low sensitivity of the GPL2025 platform. Here we conducted an in-depth analysis using six RNA-seq samples to examine the differential expression of these genes. Among the 30 NLR genes examined, 12 were able to be detected differential expression under the RNA-seq platform. However, there were still 18 NLR genes that could not be detected. So we further explored the distribution of cis-regulatory elements and possible transposons within or adjacent to these 18 NLR genes, but did not find any valuable information.

\section{Conclusions}

430 regular NLR genes were identified in rice (Nipponbare). 397 rice NLR genes were expressed at low/medium level, and 10 rice NLR genes showed high levels of expression. 400 rice NLR genes were differentially expressed in at least one sample analyzed. 46 rice NLR genes were differentially expressed in response to both Xoo and Mor. Six cis-regulatory elements are occurring frequently in rice NLR promoter regions.

\section{Methods}

Identification of rice (Nipponbare) regular NLR genes at the genome level

Nipponbare protein sequences were downloaded from the Rice Genome Annotation Project Release 7 (MSU 7.0, http://rice.plantbiology.msu.edu). All the predicted rice protein sequences were used to perform a domain search for the identification of the rice NLR family members with the NBS and LRR domains through the Interproscan (version 5.31-70.0-64) tool (Jones et al. 2014) against several latest databases including Pfam(31.0), Superfamily(1.75), SMART(7.1), and Gene3D(4.2.0) protein databases. If multiple probes hit the same gene, the average was assigned to the gene.

Collection of the microarray datasets infected by Xoo and Mor in rice

In this work, all the rice microarray data were obtained from the NCBI Gene Expression Omnibus (GEO) database (https://www.ncbi.nlm.nih.gov/geo/). These data sets were selected on the basis of the following criteria: plant materials should come from different genotypes of rice; the platform source of microarray must be from the Affymetrix Rice Genome Array GPL2025; the experiments were all under the Xoo- or Mor-infected conditions. Totally, 69 sets of experiments, including 51 Xoo-infected samples, 18 Mor-infected samples, and their control samples, were fully analyzed (Table S2). All the series consist of the samples from a variety of conditions, e.g., different growth conditions, tissues, and treatments (Table S2). 
Identification of rice NLR genes responsive to Xoo and Mor infections

Differential expression analysis of all the 69 sets of experiments was performed using the GEO2R, an interactive web tool focusing on sample comparisons (https://www.ncbi.nlm.nih.gov/geo/geo2r/). GEOquery and limma R packages from the Bioconductor project were used to extract and analyze the data (Davis and Meltzer 2007; Law et al. 2016). To further identify the differentially expressed NLR genes (de_NLRs), Fisher's combined probability test ( $p$-value $<0.05$ ) was used to initially filter genes with no differential expression. Then, a more stringent criterion was used to query the robust pathogen-responsive NLR genes: each gene showed a higher expression pattern (greater or equal to 1.5 fold-change, $p$-value < 0.01 ) in at least 17 of the 69 samples. The robust pathogen-responsive NLR genes were further validated by public RNA-seq data from six experiments (Bagnaresi et al. 2012; Jain et al. 2017; Zhang et al. 2018; Zhang et al. 2016).

Quantitative Real-Time PCR (qRT-PCR) Validation of selected rice NLR genes

The leaves of two-week-old Nipponbare seedlings were infiltrated with Xoo strain PXO99A at $\mathrm{OD}_{600}=2.0$. At $24 \mathrm{~h}$ post-inoculation (hpi), the rice leaf total RNAs were isolated by TRIzol reagent (Invitrogen, USA) according to the manufacturer's instructions. EasyScript ${ }^{\circledR}$ One-Step gDNA Removal and cDNA Synthesis Supermix (Transgen Biotech) were used for CDNA synthesis. qRT-PCR primers (Table S8) were designed by Primer Premier 5. Experiments were performed on 96-well plates with ABI7500 Real-Time PCR System (Applied Biosystems, USA) using an TransStart® Tip Green qPCR SuperMix (Transgen Biotech). Each reaction was performed at least three biological replicates and OsActin gene was used as an internal control for data normalization. The $2^{-\Delta \Delta C T}$ algorithm (Livak and Schmittgen 2001) was employed to evaluate the relative expression levels of the NLR genes.

Identification of the cis-regulatory elements in the promoters of the NLR genes in rice

According to the method (Kong et al. 2018), putative cis-regulatory elements in the promoters of rice NLR genes were identified. In brief, four pathogen-inducible cis-regulatory elements (PICEs) (AS-1, G-box, GCCbox, and H-box) were used to perform a PICE search on the rice NLR genes, and the PlantCARE tool (http://bioinformatics.psb.ugent.be/webtools/plantcare/html/) was also used for querying other cisregulatory elements in the promoter regions of rice NLR genes.

\section{Abbreviations}

CC:coiled-coil domain; CNL:CC-NBS-LRR; DEGs:differentially expressed genes; de_NLRs:differentially expressed NLR genes; GEO:Gene Expression Omnibus; Mor:Magnaporthe oryzae; NLR:Nucleotide-binding site, leucine-rich repeat genes; PAMP:pathogen-associated molecular pattern; PICEs:pathogen-inducible cis-regulatory elements; PTI:PAMP-triggered immunity; qRT-PCR:quantitative Real-Time PCR; R:resistance gene; TIR:toll interleukin-1 receptor domain; TNL:TIR-NBS-LRR; Xoo:Xanthomonas oryzae pv. oryzae 


\section{Additional Files}

Figure S1. Gene enrichment analysis of 407 rice NLR genes in 69 samples. The result shows the proportion of differentially expressed rice NLR genes in overall differentially expressed rice genes induced by the corresponding pathogen.

Figure S2. The heat map analysis of all the 38 rice $N L R$ genes based on the log 2 fold-change (FC) between the infected and control samples. Red represents up-regulated expression and green represents down-regulated expression. Each column represents a microarray sample and each row represents a NLR gene. Columns are clustered using hierarchical clustering.

Table S1. List of 430 rice NLR genes and their corresponding probes. For each gene, the locus name according to MSU Rice Genome Annotation Project, the type of subclass and the name of the Affymetrix probe are provided.

Table S2. The experimental conditions of microarray datasets used in this study. All the expression profiles were based on the Affymetrix Rice Genome Array (GPL2025).

Table S3. The expression levels of 407 rice $N L R$ genes in 69 microarray samples. $L$ means low expression level with the $\mathrm{p}$-value of $0 \sim 0.5 ; \mathrm{M}$ means medium expression level with the $\mathrm{p}$-value of $1.0 \sim 1.5 ; \mathrm{H}$ means high expression level with the $p$-value of more than 1.5 .

Table S4. The total number of differentially expressed NLR genes detected in 69 microarray samples. A gene is defined as differentially expressed if its $p$-value is lower than 0.05 .

Table S5. The number of total differentially expressed rice $N L R$ genes identified from the microarray data infected by $\mathrm{XoO}$ and Mor.

Table S6. Gene enrichment analysis of 407 rice NLR genes in the 69 microarray samples and 6 RNA-seq samples. Each sample was estimated by "P-value", "95 percent confidence interval" and "Sample estimates (odds ratio)".

Table S7. The proportion of differentially expressed rice $N L R$ genes in all the differentially expressed genes in rice.

Table S8. 38 NLR genes with differential expression in rice response to Xoo and Morinfections.

\section{Declarations}

\section{Acknowledgments}

The authors would like to thank Professor Gongyou Chen at School of Agriculture and Biology/State Key Laboratory of Microbial Metabolism, Shanghai Jiao Tong University for his critical reading of the manuscript. 
Availability of data and materials

The datasets supporting the conclusions of this article are included within the article and additional files.

\section{Authors' contributions}

WK conceived and designed this study. WK, AL, and LZ supervised the study design. LD analyzed most of the data. LD and XMX carried out the qRT-PCR assays. LD wrote the manuscript. WK edited the manuscript. XX and SZ analyzed part of the data. All the authors read, reviewed and approved the final manuscript.

\section{Ethics approval and consent to participate}

Not applicable.

\section{Consent for publication}

Not applicable.

\section{Competing interests}

The authors declare that they have no competing interests.

\section{Funding}

This work was partially sponsored by Shandong Provincial Key Laboratory of Agricultural Microbiology Open Fund (SDKL2017015).

\section{References}

1. Ambawat S, Sharma P, Yadav NR, Yadav RC (2013) MYB transcription factor genes as regulators for plant responses: an overview. Physiol Mol Biol Plants 19:307-321. https://doi.org/10.1007/s12298013-0179-1

2. Bagnaresi P, Biselli C, Orru L, Urso S, Crispino L, Abbruscato P, Piffanelli P, Lupotto E, Cattivelli L, Vale G (2012) Comparative transcriptome profiling of the early response to Magnaporthe oryzae in durable resistant vs susceptible rice (Oryza sativa) genotypes. PLoS One 7:e51609. https://doi.org/10.1371/journal.pone.0051609

3. Boter M, Ruiz-Rivero O, Abdeen A, Prat S (2004) Conserved MYC transcription factors play a key role in jasmonate signaling both in tomato and Arabidopsis. Genes Dev 18:1577-1591. https://doi.org/10.1101/gad.297704

4. Chen X, Ronald PC (2011) Innate immunity in rice. Trends Plant Sci 16:451-459. https://doi.org/10.1016/j.tplants.2011.04.003 
5. Chen ZX, Zhao W, Zhu XB, Zou CD, Yin JJ, Chern M, Zhou XG, Ying H, Jiang XZ, Li Y, Liao HC, Cheng M, Li WT, He M, Wang J, Wang JC, Ma BT, Wang JR, Li SG, Zhu LH, Chen XW (2018) Identification and characterization of rice blast resistance gene Pid4 by a combination of transcriptomic profiling and genome analysis. Journal of Genetics and Genomics 45:663-672. https://doi.org/10.1016/j.jgg.2018.10.007

6. Davis S, Meltzer PS (2007) GEOquery: a bridge between the Gene Expression Omnibus (GEO) and BioConductor. Bioinformatics 23:846-1847. https://doi.org/10.1093/bioinformatics/btm254

7. Despres C, DeLong C, Glaze S, Liu E, Fobert PR (2000) The Arabidopsis NPR1/NIM1 protein enhances the DNA binding activity of a subgroup of the TGA family of bZIP transcription factors. Plant Cell 12:279-290. https://doi.org/10.1105/tpc.12.2.279

8. DeYoung BJ, Innes RW (2006) Plant NBS-LRR proteins in pathogen sensing and host defense. Nat Immunol 7:1243-1249. https://doi.org/10.1038/ni1410

9. Dodds PN, Rathjen JP (2010) Plant immunity: towards an integrated view of plant-pathogen interactions. Nat Rev Genet 11:539-548. https://doi.org/10.1038/nrg2812

10. Droge-Laser W, Kaiser A, Lindsay WP, Halkier BA, Loake GJ, Doerner P, Dixon RA, Lamb C (1997) Rapid stimulation of a soybean protein-serine kinase that phosphorylates a novel bZIP DNA-binding protein, G/HBF-1, during the induction of early transcription-dependent defenses. EMBO J 16:726738. https://doi.org/10.1093/emboj/16.4.726

11. Dubos C, Stracke R, Grotewold E, Weisshaar B, Martin C, Lepiniec L (2010) MYB transcription factors in Arabidopsis. Trends Plant Sci 15:573-581. https://doi.org/10.1016/j.tplants.2010.06.005

12. Fang Q, Wang Q, Mao H, Xu J, Wang Y, Hu H, He S, Tu J, Cheng C, Tian G, Wang X, Liu X, Zhang C, Luo K (2018) AtDIV2, an R-R-type MYB transcription factor of Arabidopsis, negatively regulates salt stress by modulating ABA signaling. Plant Cell Rep 37:1499-1511. https://doi.org/10.1007/s00299018-2321-6

13. Feng HL, Ma NN, Meng X, Zhang S, Wang JR, Chai S, Meng QW (2013) A novel tomato MYC-type ICE1-like transcription factor, SIICE1a, confers cold, osmotic and salt tolerance in transgenic tobacco. Plant Physiol Biochem 73:309-320. https://doi.org/10.1016/j.plaphy.2013.09.014

14. Franco-Zorrilla JM, Lopez-Vidriero I, Carrasco JL, Godoy M, Vera P, Solano R (2014) DNA-binding specificities of plant transcription factors and their potential to define target genes. Proc Natl Acad Sci U S A 111:2367-2372. https://doi.org/10.1073/pnas.1316278111

15. Fujita Y, Fujita M, Satoh R, Maruyama K, Parvez MM, Seki M, Hiratsu K, Ohme-Takagi M, Shinozaki K, Yamaguchi-Shinozaki K (2005) AREB1 is a transcription activator of novel ABRE-dependent ABA signaling that enhances drought stress tolerance in Arabidopsis. Plant Cell 17:3470-3488. https://doi.org/10.1105/tpc.105.035659

16. Gu K, Yang B, Tian D, Wu L, Wang D, Sreekala C, Yang F, Chu Z, Wang GL, White FF, Yin Z (2005) $R$ gene expression induced by a type-III effector triggers disease resistance in rice. Nature 435:11221125. https://doi.org/10.1038/nature03630 
17. Hur YJ, Cho JH, Park HS, Noh TH, Park DS, Lee JY, Sohn YB, Shin D, Song YC, Kwon YU, Lee JH (2016) Pyramiding of two rice bacterial blight resistance genes, Xa3 and Xa4, and a closely linked cold-tolerance QTL on chromosome 11. Theor Appl Genet 129:1861-1871. https://doi.org/10.1007/s00122-016-2744-9

18. Jain P, Singh PK, Kapoor R, Khanna A, Solanke AU, Krishnan SG, Singh AK, Sharma V, Sharma TR (2017) Understanding host-pathogen interactions with expression profiling of NILs carrying rice-blast resistance Pi9 Front Plant Sci 8:93. https://doi.org/10.3389/fpls.2017.00093

19. Jones JD, Dangl JL (2006) The plant immune system. Nature 444:323-329. https://doi.org/10.1038/nature05286

20. Jones P, Binns D, Chang HY, Fraser M, Li W, McAnulla C, McWilliam H, Maslen J, Mitchell A, Nuka G, Pesseat S, Quinn AF, Sangrador-Vegas A, Scheremetjew M, Yong SY, Lopez R, Hunter S (2014) InterProScan 5: genome-scale protein function classification. Bioinformatics 30:1236-1240. https://doi.org/10.1093/bioinformatics/btu031

21. Khatri P, Sirota M, Butte AJ (2012) Ten years of pathway analysis: current approaches and outstanding challenges. PLoS Comput Biol 8:e1002375. https://doi.org/10.1371/journal.pcbi.1002375

22. Kong W, Ding L, Cheng J, Wang B (2018) Identification and expression analysis of genes with pathogen-inducible cis-regulatory elements in the promoter regions in Oryza sativa. Rice (N Y) 11:52. https://doi.org/10.1186/s12284-018-0243-0

23. Law CW, Alhamdoosh M, Su S, Dong X, Tian L, Smyth GK, Ritchie ME (2016) RNA-seq analysis is easy as 1-2-3 with limma, Glimma and edgeR. F1000Res 5. https://doi.org/10.12688/f1000research.9005.3

24. Li Q, Chen F, Sun LX, Zhang ZQ, Yang YN, He ZH (2006) Expression profiling of rice genes in early defense responses to blast and bacterial blight pathogens using cDNA microarray. Physiological and Molecular Plant Pathology 68:51-60. https://doi.org/10.1016/j.pmpp.2006.06.002

25. Lin HA, Chen SY, Chang FY, Tung CW, Chen YC, Shen WC, Chen RS, Wu CW, Chung CL (2018) Genome-wide association study of rice genes and loci conferring resistance to Magnaporthe oryzae isolates from Taiwan. Bot Stud 59:32. https://doi.org/10.1186/s40529-018-0248-4

26. Livak KJ, Schmittgen TD (2001) Analysis of relative gene expression data using real-time quantitative PCR and the 2(T)(-Delta Delta C) method. Methods 25:402-408. https://doi.org/10.1006/meth.2001.1262

27. Loake GJ, Faktor O, Lamb CJ, Dixon RA (1992) Combination of H-box [CCTACC(N)7CT] and G-box (CACGTG) cis elements is necessary for feed-forward stimulation of a chalcone synthase promoter by the phenylpropanoid-pathway intermediate p-coumaric acid. Proc Natl Acad Sci U S A 89:92309234. https://doi.org/10.1073/pnas.89.19.9230

28. McHale L, Tan X, Koehl P, Michelmore RW (2006) Plant NBS-LRR proteins: adaptable guards. Genome Biol 7:212. https://doi.org/10.1186/gb-2006-7-4-212 
29. Meyers BC, Kozik A, Griego A, Kuang H, Michelmore RW (2003) Genome-wide analysis of NBS-LRRencoding genes in Arabidopsis. Plant Cell 15:809-834. https://doi.org/10.1105/tpc.009308

30. Moffat AS (2001) Finding new ways to fight plant diseases. Science 292:2270-2273. https://doi.org/10.1126/science.292.5525.2270

31. Monosi B, Wisser RJ, Pennill L, Hulbert SH (2004) Full-genome analysis of resistance gene homologues in rice. Theor Appl Genet 109:1434-1447. https://doi.org/10.1007/s00122-004-1758-x

32. Moskvina E, Imre EM, Ruis H (1999) Stress factors acting at the level of the plasma membrane induce transcription via the stress response element (STRE) of the yeast Saccharomyces cerevisiae. Molecular Microbiology 32:1263-1272. https://doi.org/DOI 10.1046/j.1365-2958.1999.01438.x

33. Narusaka Y, Nakashima K, Shinwari ZK, Sakuma Y, Furihata T, Abe H, Narusaka M, Shinozaki K, Yamaguchi-Shinozaki K (2003) Interaction between two cis-acting elements, ABRE and DRE, in ABAdependent expression of Arabidopsis $r d 29 \mathrm{~A}$ gene in response to dehydration and high-salinity stresses. Plant Journal 34:137-148. https://doi.org/DOI 10.1046/j.1365-313X.2003.01708.x

34. Ogata K, Morikawa S, Nakamura H, Sekikawa A, Inoue T, Kanai H, Sarai A, Ishii S, Nishimura Y (1994) Solution structure of a specific DNA complex of the Myb DNA-binding domain with cooperative recognition helices. Cell 79:639-648. https://doi.org/10.1016/0092-8674(94)90549-5

35. Onaga G, Wydra K, Koopmann B, Chebotarov D, Sere Y, Von Tiedemann A (2017) High temperature effects on Pi54 conferred resistance to Magnaporthe oryzae in two genetic backgrounds of Oryza sativa. J Plant Physiol 212:80-93. https://doi.org/10.1016/j.jplph.2017.02.004

36. Sarkar S, Das A, Khandagale P, Maiti IB, Chattopadhyay S, Dey N (2018) Interaction of Arabidopsis TGA3 and WRKY53 transcription factors on Cestrum yellow leaf curling virus (CmYLCV) promoter mediates salicylic acid-dependent gene expression in planta. Planta 247:181-199. https://doi.org/10.1007/s00425-017-2769-6

37. Seo YS, Sriariyanun M, Wang L, Pfeiff J, Phetsom J, Lin Y, Jung KH, Chou HH, Bogdanove A, Ronald $\mathrm{P}$ (2008) A two-genome microarray for the rice pathogens Xanthomonas oryzae pv. oryzae and oryzae pv. oryzicola and its use in the discovery of a difference in their regulation of hrp genes. BMC Microbiol 8:99. https://doi.org/10.1186/1471-2180-8-99

38. Singh K, Foley RC, Onate-Sanchez L (2002) Transcription factors in plant defense and stress responses. Curr Opin Plant Biol 5:430-436. https://doi.org/10.1016/s1369-5266(02)00289-3

39. Tarr DE, Alexander HM (2009) TIR-NBS-LRR genes are rare in monocots: evidence from diverse monocot orders. BMC Res Notes 2:197. https://doi.org/10.1186/1756-0500-2-197

40. Toledo-Ortiz G, Huq E, Quail PH (2003) The Arabidopsis basic/helix-loop-helix transcription factor family. Plant Cell 15:1749-1770 https://doi.org/10.1105/tpc.013839

41. Ulmasov T, Hagen G, Guilfoyle T (1994) The ocs element in the soybean GH2/4 promoter is activated by both active and inactive auxin and salicylic acid analogues. Plant Mol Biol 26:1055-1064

42. Urso S, Desiderio F, Biselli C, Bagnaresi P, Crispino L, Piffanelli P, Abbruscato P, Assenza F, Guarnieri G, Cattivelli L, Vale G (2015) Genetic analysis of durable resistance to Magnaporthe oryzae in the rice 
accession Gigante Vercelli identified two blast resistance loci. Mol Genet Genomics 291:17-32. https://doi.org/10.1007/s00438-015-1085-8

43. Wu CH, Krasileva KV, Banfield MJ, Terauchi R, Kamoun S (2015) The "sensor domains" of plant NLR proteins: more than decoys? Front Plant Sci 6:134. https://doi.org/10.3389/fpls.2015.00134

44. Wu J, Jiang Y, Liang Y, Chen L, Chen W, Cheng B (2019) Expression of the maize MYB transcription factor ZmMYB3R enhances drought and salt stress tolerance in transgenic plants. Plant Physiol Biochem 137:179-188. https://doi.org/10.1016/j.plaphy.2019.02.010

45. Xiang C, Miao ZH, Lam E (1996) Coordinated activation of as-1-type elements and a tobacco glutathione S-transferase gene by auxins, salicylic acid, methyl-jasmonate and hydrogen peroxide. Plant Mol Biol 32:415-426

46. Yang S, Feng Z, Zhang X, Jiang K, Jin X, Hang Y, Chen JQ, Tian D (2006) Genome-wide investigation on the genetic variations of rice disease resistance genes. Plant Mol Biol 62:181-193. https://doi.org/10.1007/s11103-006-9012-3

47. Yang S, Li J, Zhang X, Zhang Q, Huang J, Chen JQ, Hartl DL, Tian D (2013) Rapidly evolving R genes in diverse grass species confer resistance to rice blast disease. Proc Natl Acad Sci U S A 110:1857218577. https://doi.org/10.1073/pnas. 1318211110

48. Zhang F, Huang LY, Zhang F, Hu DD, Wu WJ, Wang WS, Ali J, Cruz CV, Zhou YL, Li ZK (2015) Interacting transcriptomes revealing molecular mechanisms underlying Xa39 mediated broad spectrum resistance of rice to bacterial blight. Plant Genome 8. https://doi.org/10.3835/plantgenome2014.12.0094

49. Zhang J, Chen L, Fu C, Wang L, Liu H, Cheng Y, Li S, Deng Q, Wang S, Zhu J, Liang Y, Li P, Zheng A (2017) Comparative transcriptome analyses of gene expression changes triggered by Rhizoctonia solani AG1 IA infection in resistant and susceptible rice varieties. Front Plant Sci 8:1422. https://doi.org/10.3389/fpls.2017.01422

50. Zhang J, Zhao W, Fu R, Fu C, Wang L, Liu H, Li S, Deng Q, Wang S, Zhu J, Liang Y, Li P, Zheng A (2018) Comparison of gene co-networks reveals the molecular mechanisms of the rice (Oryza sativa) response to Rhizoctonia solani AG1 IA infection. Funct Integr Genomics 18:545-557. https://doi.org/10.1007/s10142-018-0607-y

51. Zhang Y, Zhao J, Li Y, Yuan Z, He H, Yang H, Qu H, Ma C, Qu S (2016) Transcriptome analysis highlights defense and signaling pathways mediated by rice $P i 21$ gene with partial resistance to Magnaporthe oryzae. Front Plant Sci 7:1834. https://doi.org/10.3389/fpls.2016.01834

52. Zhou T, Wang Y, Chen JQ, Araki H, Jing Z, Jiang K, Shen J, Tian D (2004) Genome-wide identification of NBS genes in japonica rice reveals significant expansion of divergent non-TIR NBS-LRR genes. Mol Genet Genomics 271:402-415. https://doi.org/10.1007/s00438-004-0990-z

53. Zipfel C (2008) Pattern-recognition receptors in plant innate immunity. Curr Opin Immunol 20:10-16. https://doi.org/10.1016/j.coi.2007.11.003

\section{Figures}




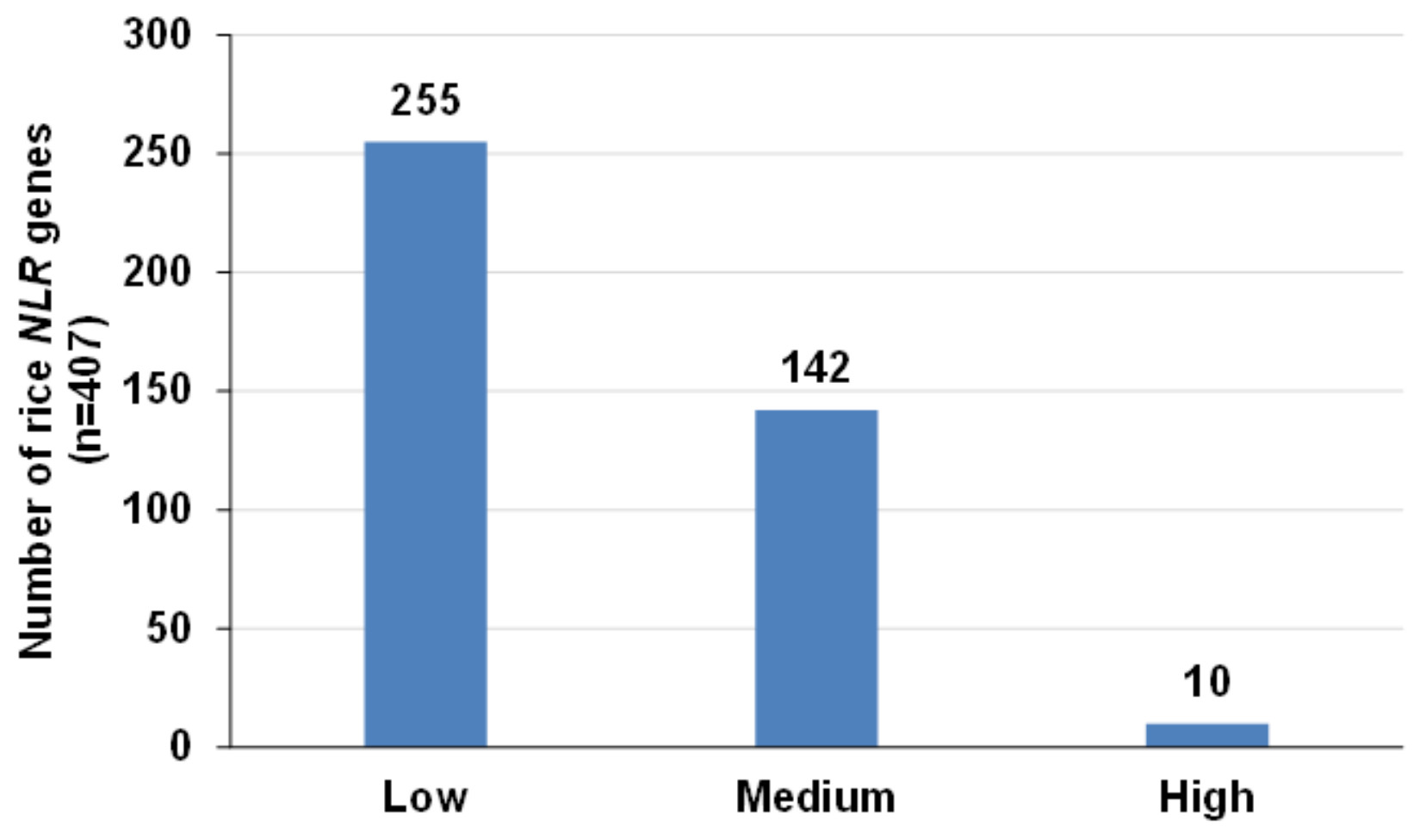

Figure 1.

\section{Figure 1}

Analysis of gene expression level for 407 rice NLR genes in 69 microarray samples based on the foldchange (FC) between infected and control samples. The expression levels are divided into three groups: "Low" (FC < 1), "Medium" (1 $\leq$ FC < 1.5) and "High" (FC $\geq 1.5)$, respectively. 


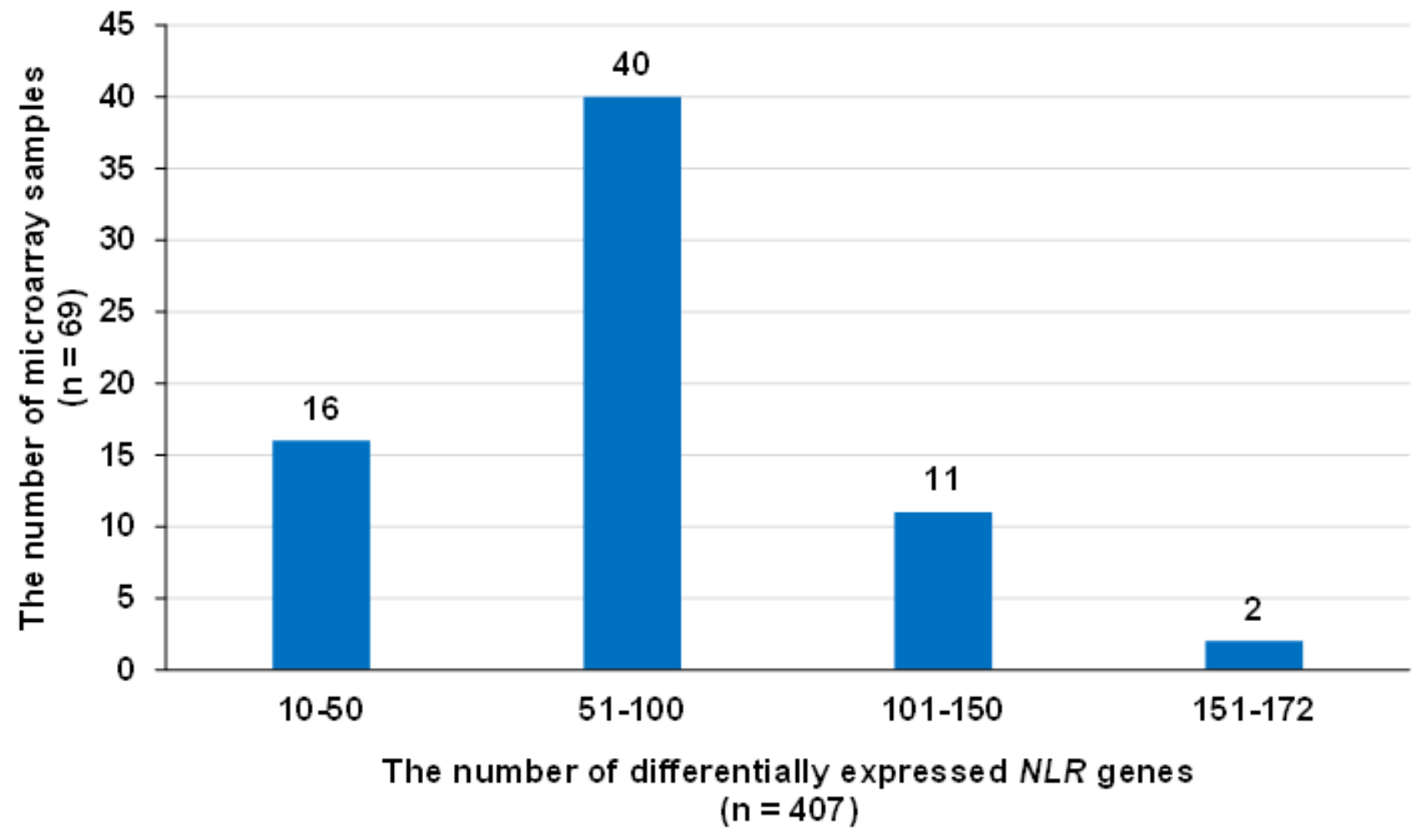

Figure 2.

Figure 2

The frequency of occurrence of differentially expressed rice NLR genes in 69 microarray samples. The screening criteria for differential expressed genes are p.value $<0.05$. 


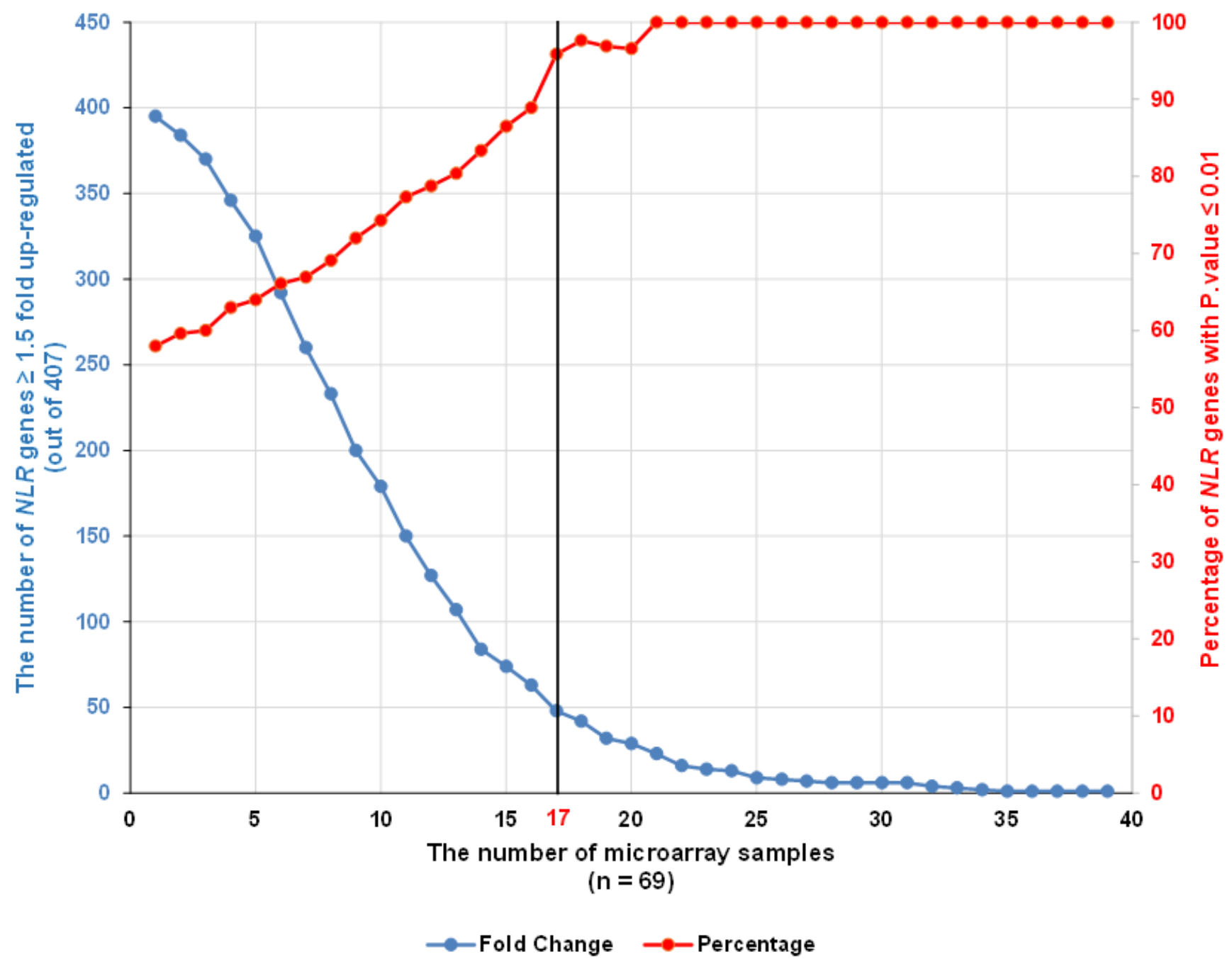

Figure 3.

Figure 3

Selection of filters used for analysis of the rice microarray data in this study. Determination of the number of rice NLR genes being up-regulated at least 1.5 -fold in at least the number of microarray experiments indicated on the $x$ axis (blue line, left $y$ axis), plotted along with the percentage of those genes with $P \leq$ 0.01 (red line, right y axis). 


\section{de_NLR genes identified by microarray}

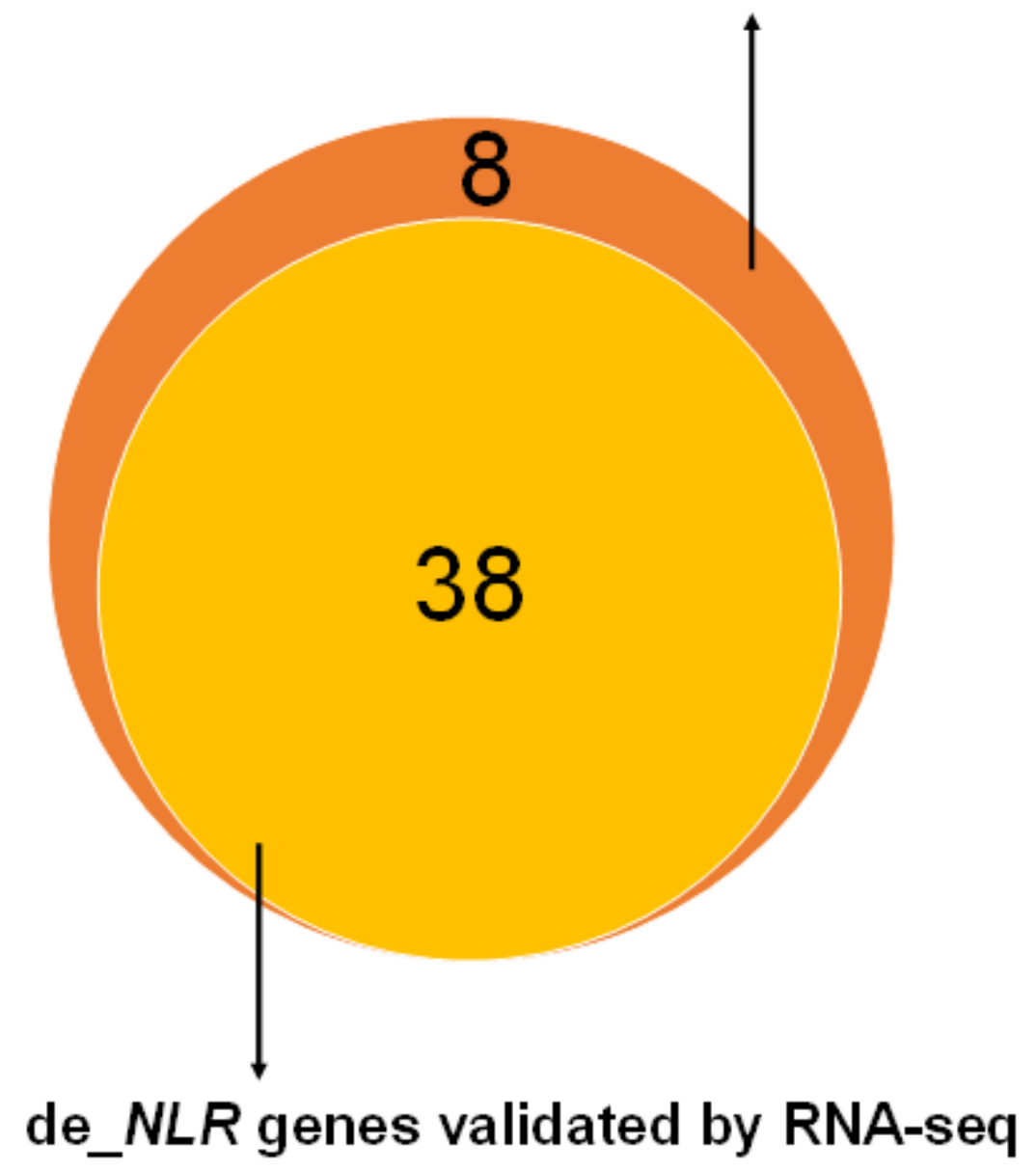

\section{Figure 4.}

Figure 4

A Venn diagram of differentially expressed rice NLR genes (de_NLRs) between rice microarray and RNASeq data.. The overlap illustrates the overlaps in de_NLRs identified by microarray data and RNA-seq data. 


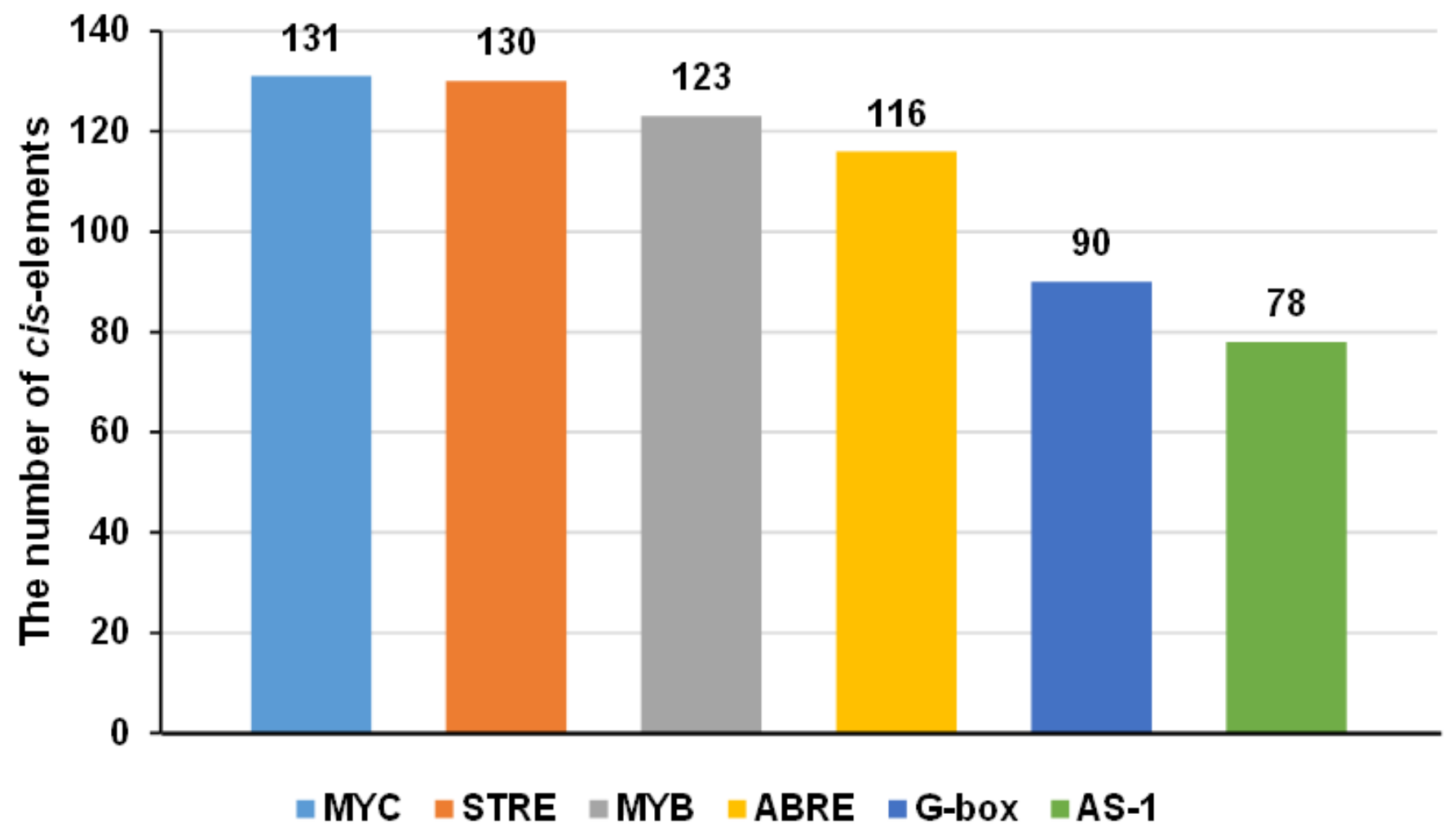

Figure 5.

Figure 5

The classification of putative cis-regulatory elements in the promoter regions of 38 rice NLR genes. 

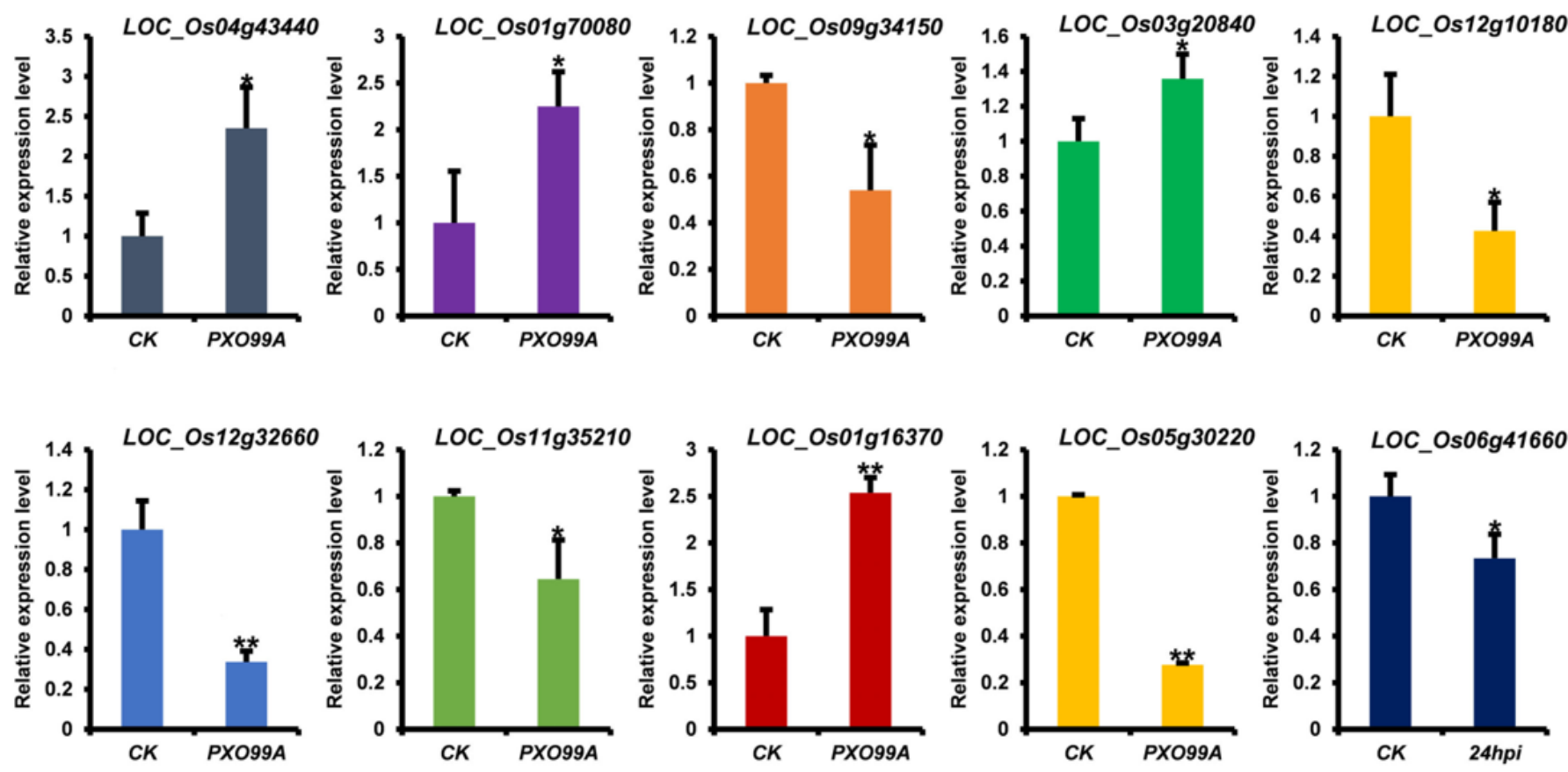

Figure 6.

Figure 6

qRT-PCR analysis of selected rice NLR genes. OsActin was employed as an internal control. Gene expression differences between treatment and control was carried out by one-way analysis of variance (ANOVA) analysis. Error bars denote the standard deviation calculated from three technical replicates. * denotes statistical significance ( $p$-value $\leq 0.05)$, and $* *$ denotes high statistical significance ( $p$-value $\leq$ $0.01)$.

\section{Supplementary Files}

This is a list of supplementary files associated with this preprint. Click to download.

- TabS3Theexpressionlevelsof407riceNLRgenes.xlsx

- FigS1GeneenrichmentofNLRs.docx

- TabS838NLRgenesshoweddifexpression.xIsx

- TabS4numberofdifexpressedNLRgenes.xlsx

- TabS5difexpressedriceNLRgenes.xIsx

- TabS7proportionofdifexpressedriceNLRgenes.xlsx

- TabS6enrichmentof407riceNLRgenes.xlsx 
- TabS1riceNLRgenesandprobes.xIsx

- TabS2Theexperimentalconditions.xlsx

- FigS2Theheatmapof38riceNLRgenes.docx 